\section{A MODIFIED BANK OF AMMONIA STILLS}

By FRED BERRY AND I. H. VAN BUSKIRK Received September 2, 1913

No doubt a majority of those in charge of laboratories where ammonia determinations are made, have been confronted, at one time or another, with the problem of designing or choosing some form of apparatus to be used for such determinations. Just such a problem had to be solved by the writers last year when plans were prepared for moving our laboratory into new quarters. The old bank of stills which had been in use here for many years had one large tank used as a condenser for the eight stills and the lower ends of the block-tin pipes were so located that one had to reach under a framework supporting the burners and flasks in order to replace or remove the nessler jars. This apparatus was in many respects far from satisfactory, but for one reason or another had not been replaced by a more convenient type.

When the necessity for such a change arose we were unable to secure much help in the way of drawings, specifications, etc., from other laboratories. We did, however, receive a photograph of an apparatus, of which this is a modification, but found some diffculty in estimating dimensions, etc., from a photograph alone. It occurred to the writers, therefore, that detailed specifications and drawings of this apparatus would be of great assistance to other workers who might care to duplicate it or construct a modification of it. While no claim is made for originality of principle, we do believe

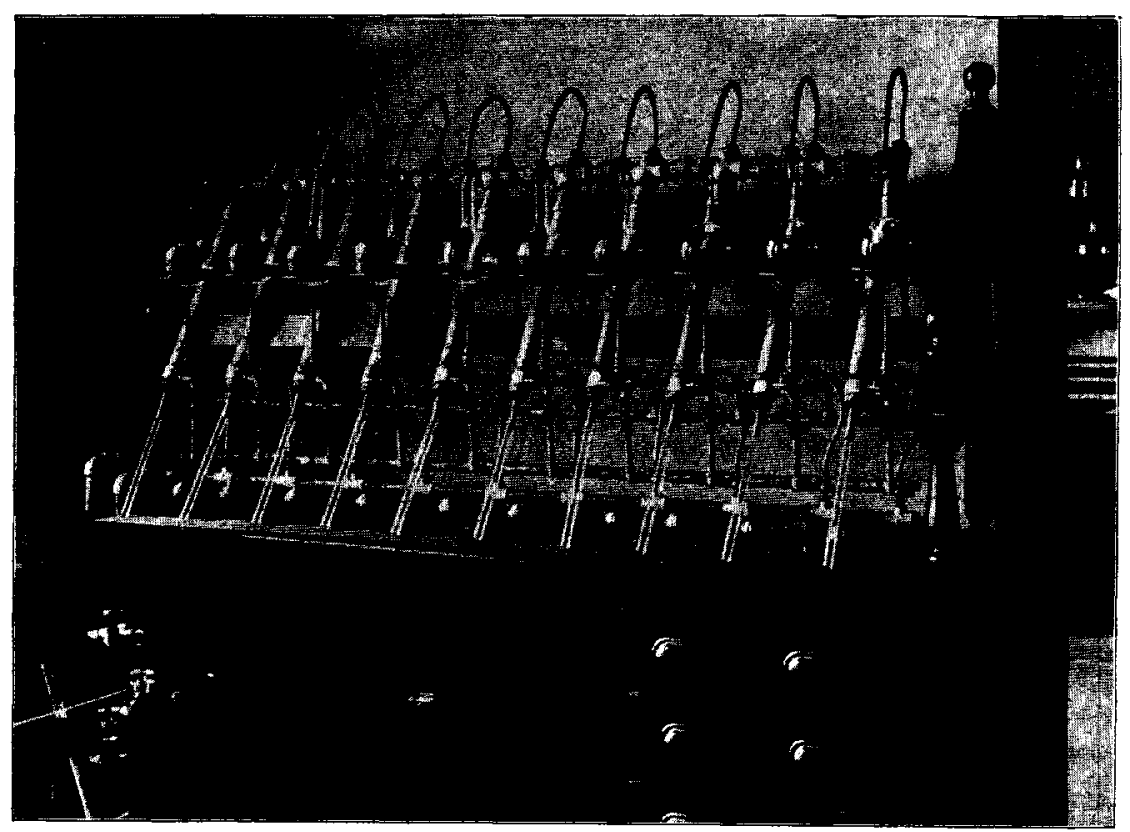

Photograph of Entire Apparatus on Laboratory Bench

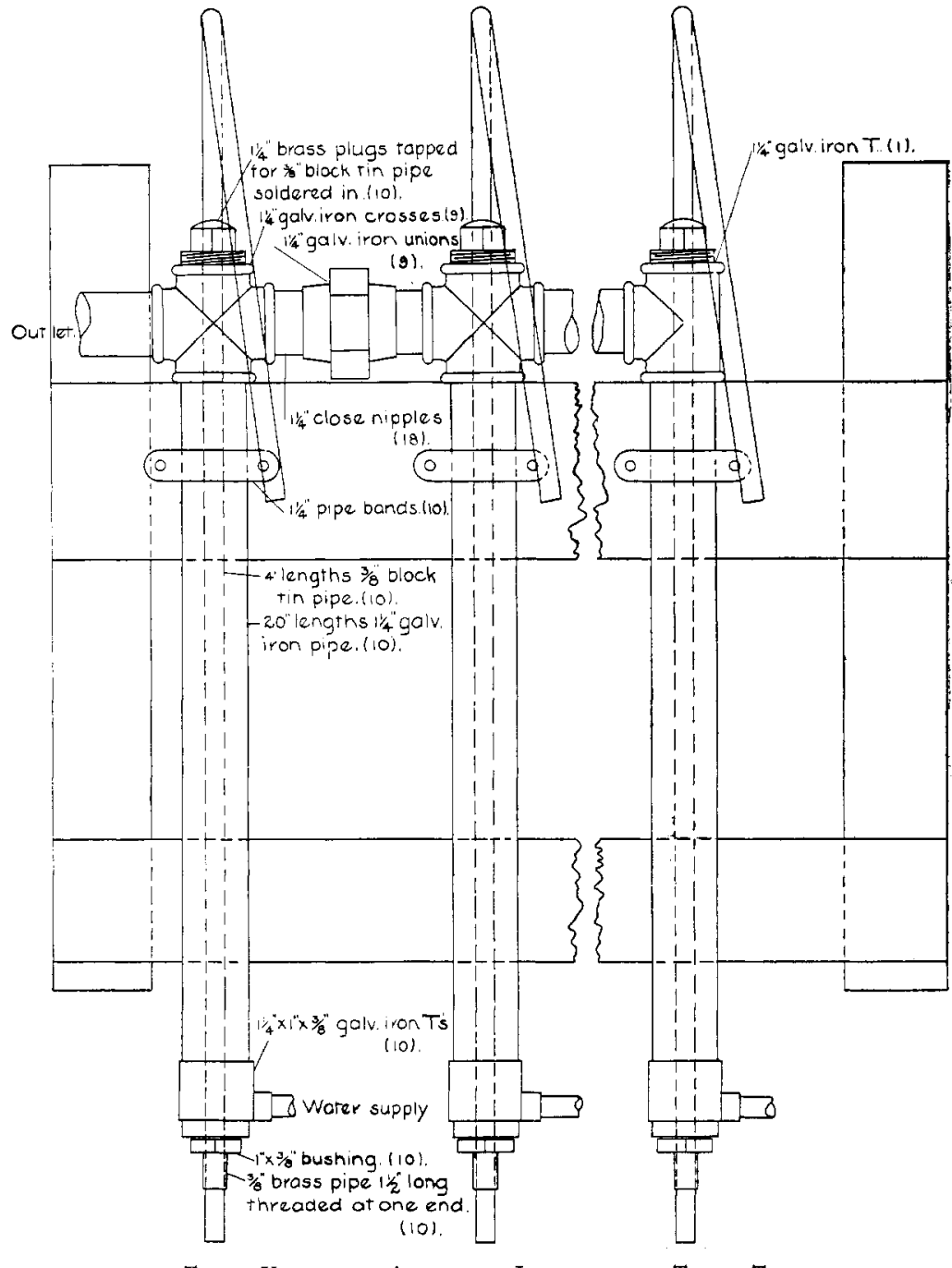

Front VIEW from Above the LeVEL OF The TABLE TOP that some of the improvements added to former types are of distinct advantage and worthy of note.

The distinguishing points of this apparatus, in common with others of similar style, when compared with the majority of other forms are:

I. Unit construction, i. e., each still has an individual condenser.

This means:

(a) Repairs can be made on one unit while others are in operation.

(b) Additional units can be added without much extra cost or trouble.

2. The distinguishing features of this type alone are:

(a) All ring supports for flasks and burners are attached to standards in the rear of the condensers, thus allowing free access to the flasks. The advantage of this will be apparent to those who have worked with the style where the uprights for the sup. port of the flask rings projected above and were in front of the flasks. 

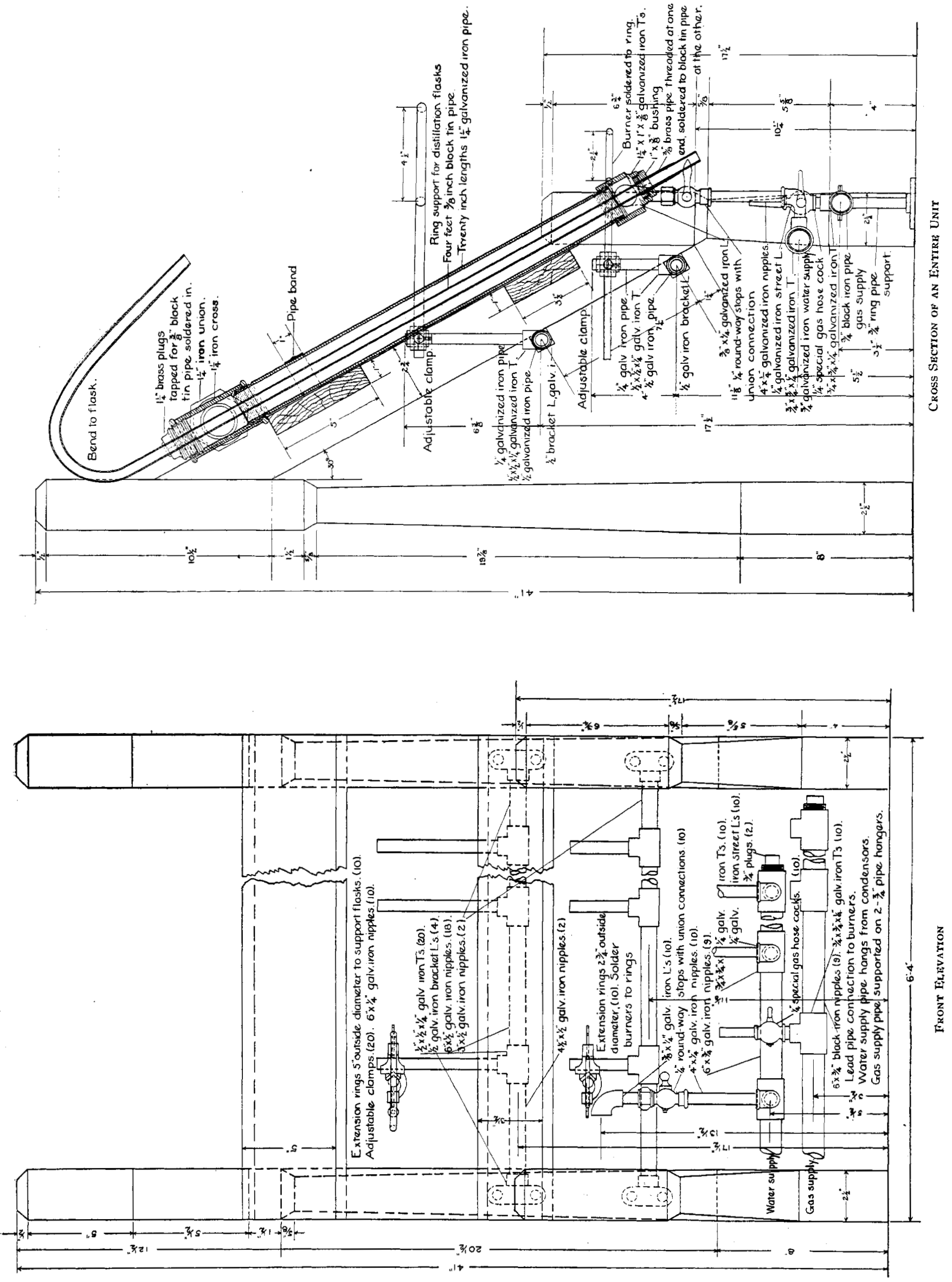
(b) The block-tin pipes are soldered into brass nipples at the lower end and into brass plugs at the upper end of the condensers. This provides a perfectly tight joint and gives a certain amount of rigidity to the lower end of the tin pipes.

OHIO STATE BOARD OF HEALTH

Columbus, Ohio

\section{ADDRESSES}

\section{OUR RADIUM RESOURCES}

By Charles L. Parsons²

The "wonders of radium," both fact and fable, have been treated so extensively in the scientific and public press that it is not my intention, nor is it at all necessary to repeat them here. Rather it is my wish to-day to present to a body of men interested in the development of American mining the present commercial situation as regards radium and its ores, and to point out, so far as I may, some of those future developments that already begin to be more or less distinctly visible.

A bulletin on the radium, uranium and vanadium situation, by R. B. Moore, physical chemist in charge of the Denver office of the Bureau of Mines, and K. L. Kithil, mineral technologist of the Bureau, will appear within a few weeks and will contain much detail of interest to the mining industry. Last April an advance statement, authorized by the Director, regarding this bulletin, brought out particularly the fact that practically all of the carnotite ore mined in the world in 1912 was shipped abroad and that this country was furnishing annually nearly three times as much radium from its Colorado carnotite deposits as all the rest of the world put together. It was further pointed out that this material has been bought by European buyers at a price entirely incommensurate with its radium value and that efforts should be made to keep at home both the radium itself and the profits of its manufacture; also that too much stress could not be laid upon the extensive waste of valuable radium ore thrown on the dumps of mines and prospects--much of it under such conditions that it could never be recovered.

The publication of this statement has already resulted in an increase of at least 33 per cent in the price of carnotite ore, and European buyers are awakening to the fact that they must pay to the American miner a price nearer the actual value of his ore. Also, a much lower grade of ore is now marketable, for whereas six months ago ore containing 2 per cent uranium oxide was the lowest grade accepted by European buyers, agents of these buyers are now asking for and actually purchasing ore containing no more than half this content of uranium. Furthermore, the operators are taking more care in separating their low-grade ore from the gangue and in protecting it from wind and weather. Moreover, old dumps are being sold and ore that a few months ago was thrown aside as valueless will be recovered from them.

In this paper I shall refer to other facts contained in this bulletin and shall mention some new developments having a direct bearing upon the American radium industry which have taken place since the manuscript was sent to the printer.

As is well known to all of you, the popular belief has been that the chief source of radium is the mineral pitchblende, especially that obtained from the mines now under the control of the Austrian government at Joachimsthal, Bohemia, and pitchblende is the richest and most eagerly soughit uranium radium ore. Outside of the ore in Austria, the only pitchblende deposits of any size are those in Gilpin County, Colorado, from which some 30 tons more or less have been procured since the mineral became valuable as a source of radium. The Denver papers recently announced that these pitchblende-bearing mines have been acquired by Alfred I. duPont of Wilmingtor, Delaware, and it is greatly to be hoped that their exploitation under his direction

1 Paper presented before the Anerican Mining Congress, Philadelphia, October 23, by permission of the Director of the U. S. Bureat of Mines.

2 Chief of the Division of Mineral Technology, Bureau of Mines. will yield an increased supply of this valuable mineral. It is. not, however, so generally recognized that the mineral carnotite, which outside of the United States occurs only in low-grade ores: mixed with ilmenite in the Olray district of South Australia. and as a calcium carnotite (communicated by W. F. Hillebrand) under the name of Tyuyamyunite in Ferghana, Russian Turkestan, is by far the more important source of radium. From the most authentic sources it can be definitely stated that the Australian and Russian deposits do not compare in extent or richness with our own. The American carnotite is accordingly the largest source of radium at the present time and at least four times as much radium was mined in America in the form of carnotite in 1912 as has been produced from Colorado pitchblende since it was first discovered in that State

Outside of carnotite and pitchblende, the only other known source of radium is the mineral autunite. The autunite deposits. of Portugal have probably furnished a few milligrams of radium. to commerce, and from the Mt. Painter deposits in South Australia a few tons of autunite-bearing ores have been shipped to. London.

American carnotite is found chiefly in Montrose and San Miguel counties, Colorado, and in Utah northwest of these counties. The Utah deposits are at Green River, Table Mountain, Richardson, Fruita, Moab, and some 16 miles southeast of Thompsons. The ores of these deposits are of a lower grade than those of the Paradox Valley, but they are nearer to the railroads and transportation costs are much less. The Green River deposits have apparently become regular producers. In Colorado, prospects have been opened at Coal Creek, I4 miles north of Meeker and at Skull Creek 65 miles west of Meeker; but the richest of all American carnotite localities and indeed the richest known radium-bearing region in the world is that of the Paradox Valley, Colorado, extending from Hydraulic on the north to the McIntyre district on the south.

Geologists are now in the field making a special study of these carnotite ores with special reference to their occurrence and origin, of which altogether too little is now known. In the Paradox region the deposits seem to lie invariably just above the finegrained La Plata sandstone. This rock is usually exposed high on the sides of the canyons, some of which are excelled in extent and in natural beauty by only the Grand Canyon itself. In a few instances, as at Long Park and Club Ranch, the deposits are only a few feet under the surface, the higher formations having been eroded; but for the main part, the stratum in which the carnotite occurs, when not entirely eroded, is deep below the surface of the mesa. Accordingly prospecting is mainly carried on along the sides of the canyons, and where vanadium and uranium stains are seen upon the rock the prospector blasts his tunnel in the hope of developing a pocket of the ore. The fact that the ore occurs in pockets renders prospecting uncertain, and there appears to be no present hope of insuring a successful search for pockets that are not exposed or do not happen to be near the surface. Although it is probable that many other pockets of carnotite occur at the same geologic horizon, their discovery, except where the ore-bearing stratum has been exposed by erosion, appears at present to be an almost hopeless task. The eroded sides of the canyons have been prospected again and again but new claims are still being opened and are being sold by the prospector to the larger companies or operators who mine the ore. In such a sale the prospector 